\title{
LETTER OF LIEUT. COL. WM. E. SMALL.
}

\section{Head Quarters, 10th Iowa, Camp near Corinth, Miss., ? October 28, 1862.}

Sin-I have the honor to transmit to your Excellency, by the hand of Mr. Terry of Richmond, our Regimental Flag, which bears the marks of honorable service, received upon the fields of Charleston, New Madrid, Isłand No. 10, Farmington, Iuka and Corinth. Upon the belt plate, you will notice the mark of a ball which struck it, in the action at Corinth, while worn by Color Sergeant, Jacob Gaver. The flag staff, being behind the plate, saved his life. The oblong hole, which you will see near the centre of the flag, was eaused by a canister shot. Should it meet the approval of your Excellency, I would like to have it deposited with the State Historical Society.

Very respectfully, your ob't serv't,

WM. E. SMALI,

Lieut. Col. Commanding.

\section{LETTER OF MESSRS. J. D. FYKE, S. Q. WHITE AND OTHERS.}

Camp near Rolla, Mo., ?

December 19th, 1862.5

Plof. N. R. Leonard, Secretary of the State Historieal Society:

Dear $\mathrm{Sir}_{3}$ - We, the undersigned, take pleasure in sending to you, to be placed in the archives of the "State Historical Society," a large specimen of Stalactite. It was found in a large cave, near Waynesville, Pulaski county, Mo., on the 12 th instant. The specimen was found about three-fourths of a mile from the entrance, and was fast to the solid rock above, with points downwards, the cave being seven feet high at that point. Hoping this tribute to the Society will be gratefully received and appreciated, we have the honor to subscribe ourselves, yours respectfully,

$\left.\begin{array}{l}\text { J. D. FYKE, } \\ \text { S. Q. WHITE, } \\ \text { LARKIN GEARY, } \\ \text { JOHN BATCH, }\end{array}\right\} \begin{aligned} & \text { Members of Co. G., } \\ & 22 \mathrm{~d} \text { Reg. Iowa Inf'y. }\end{aligned}$


Copyright of Annals of Iowa is the property of State of Iowa, by \& through the State Historical Society of Iowa and its content may not be copied or emailed to multiple sites or posted to a listserv without the copyright holder's express written permission. However, users may print, download, or email articles for individual use. 